Article

\title{
Auditing the Marketing and Social Media Communication of Natural Protected Areas. How Marketing Can Contribute to the Sustainability of Tourism
}

\author{
Teodoro Luque-Martínez $₫$, Nina Faraoni $₫$ and Luis Doña-Toledo* \\ Marketing and Market Research Department, Faculty of Economics and Business, University of Granada, \\ 18071 Granada, Spain \\ * Correspondence: luisdt@ugr.es
}

Received: 21 June 2019; Accepted: 23 July 2019; Published: 24 July 2019

check for updates

\begin{abstract}
Natural Protected Areas face the challenge of conciliating attractions with satisfaction of their different stakeholders without compromising their own resources. Marketing can play an important role to this challenge from a macromarketing perspective. No studies are found in the literature on the integral assessment of marketing practices in Natural Protected Areas. For the first time, it proposes a marketing audit in Natural Protected Areas to fill that gap applying the Importance-Performance Analysis matrix, useful in strategic decisions, through interviews with directors of Natural Protected Areas. The main strengths, weaknesses, and deficits in the application of marketing are identified. The presence of a restricted and biased attitude towards marketing was noted among directors. In addition, the marketing behaviour is studied in two of the main social networks (Twitter/Facebook), comparisons were established in the USA, Spain, Italy and Mexico, identifying behavioural profiles in five groups in accordance with the 26 indicators under analysis.
\end{abstract}

Keywords: Natural Protected Areas; marketing management; social networks; national parks; marketing audit; IPA matrix; sustainable tourism

\section{Introduction}

Tourism is an activity of great dynamism that contributes to changes in the life-style of society [1] and promotes new cultural values, such as more positive attitudes towards natural spaces. The growing demand for nature-based experiences among tourists and day-trippers is altering the perception that society forms of natural spaces [2].

The attractions of natural areas are a tourism asset of immense importance. Nature tourism is a market niche with very specific characteristics [3], in particular, the segments of mountain and nature tourism are those with the highest growth rates, and their popularity has increased in recent years [4]. According to some estimates, trekking tourism and visits to protected areas account for approximately $15-20 \%$ of global tourism [5]. These activities have generated numerous studies on tourist demand and motivations in mountain and nature tourism [6,7], the costs of those activities [8] and the consumer profile [9].

One of the main motivations that brings tourists to Natural Protected Areas (NPA) is the desire to break with the daily routine [10]; hence, one of the fundamental reasons that motivates tourists is the experience of nature around the globe [11,12]. In this expanding segment of tourism, National Parks (NP) have a leading role as tourism destinations of great interest $[13,14]$.

The high demand for recreational tourism and the open air has raised a challenge for managers of NPA [15], as tourism has to be perceived as a tool for sustainability [16] and increased quality of life, 
rather than simply as a means of enriching a company [17]. It is of greater importance each day to package tourism development [18] on the basis of a better understanding of tourist behavior $[19,20]$. The challenge of NPAs lies in reconciling their attractions as a destination-providing the visitor with an agreeable experience - with the sustainable development of their environment; in other words, without compromising their natural resources [21]. From the perspective of marketing as a discipline that represents the study of transactional behaviors and their consequences for society and the environment, and therefore from a macromarketing perspective [22,23], the management of an NPA can be decoupled from neither the concept of sustainable tourism, nor from marketing and marketing techniques, which either directly or indirectly impact local communities and their economy [24]. However, attention has hardly been given to how companies and organizations that intervene in and manage natural areas have developed and adapted their marketing strategies, nor to the perspective of both directors and employees [25] on the practice of such strategies. The challenges of sustainable management that NPAs have, the need to understand their public (inhabitants and visitors in particular), to segment (in particular, sports tourism, as Matzler et al. [26] indicated), to enter into dialogue with them, to adopt positions, and to have a long-term relational orientation, all justify the need to perform an audit of marketing.

Hence, the performance of such an audit is the objective of our study that inquiries into how NPs prepare, organize, and apply the marketing tactics in general, and the management of social networks in particular. More concretely:

(1) To discover the main strengths and weaknesses in the application of marketing of NPs.

(2) To identify the main deficits in marketing management of the NPs.

(3) To identify the behaviour patterns on social media of NPs in different countries.

Knowing this, we can identify actions for a more sustainable tourism in NPA, under the basic principle of respecting their conservation.

Through the use of the Importance-Performance Analysis (IPA) matrix, the directors of NP from four countries responded to a questionnaire of 32 items in six marketing dimensions. In addition, the use of two of the best-known social media networks-Twitter and Facebook-was analysed through a comparative study between national parks in four countries (USA, Spain, Italy, Mexico), identifying five clusters according to their profiles on social networks. This approach also implies a significant novelty, as no previous studies were found that had considered the NPs of various countries and that, above all, had analysed and compared their activity through social media.

\section{Literature Review}

The origin of Natural Protected Areas (in the form of national parks or in any other form) is related to the need for their conservation, hence the importance of making visitors conscious of the history of the place, its community and its representative values. The National Park Service Organic Act of 1916 [27] established that the objective of the US system of National Parks (NPs) was to conserve their natural and historic scenery, as well as the ecosystem present in it, and to act in its best interests and with the media, so that it may be preserved for future generations [28]. The principal objective of NPs for the International Union for the Conservation of Nature (IUCN) is to protect biodiversity, emphasizing the protection of ecological structures and conserving natural processes, promoting education and entertainment (IUCN 2017) [29]. In accordance with the Protected Planet Report [30], the IUCN also works to reduce the pressure that global ecosystems are under, to increase biodiversity, through safeguards on the ecosystems and the implementation of active participation through conscientization, education, and knowledge.

The primary mission of NPs is conservation of the natural and cultural ecosystem, at the same time providing recreational opportunities for visitors. Nevertheless, it is also necessary to consider strategic priorities that are focused on both the economic and the social welfare of communities [31]. Since the emergence of NPAs, they have attracted important investments and are considered as the pillar upholding the conservation of biodiversity [32], given that they contribute environmental, physical, 
psychological, socio-cultural, and economic benefits [33]. At present, almost $15 \%$ of the globe surface area is an NPA [34].

Although there is no general consensus on the definition of the term sustainability and the term sustainable tourism [35], the idea in the collective imagination is related to the need for the conservation of rich natural spaces in biodiversity that create singular ecosystems [36]. Different governmental agencies have declared the need to reconcile the development of economic activity with sustainability in NPAs [18].

In 2012, at the United Nations Conference on Sustainable Development [37], the 17 Sustainable Development Goals (SDGs) were established. The purpose was to create a set of global objectives related to the environmental, political and economic challenges facing our world. Among such purposes there was a close link between tourism, natural areas and marketing. Goal number 12 aims to achieve "responsible production and consumption" in order to achieve efficient management of natural resources and spaces, and sustainable development that reduces the ecological footprint. This is linked to goal number 15 of "life of terrestrial ecosystems", where it is established that, although $15 \%$ of the land is protected, biodiversity remains at risk. Therefore, measures in the management of the natural heritage and its preservation turned out to be urgent. In this context, marketing is a tool that should contribute to these objectives.

In this way, there has been greater public awareness of the consequences of excessive consumption and exploitation of natural spaces and the need to use marketing as a technique for promoting change in sustainable behaviour [38,39].

\section{NPs and Marketing as Management of Relations}

The directors of NPs constantly find themselves facing the dilemma of managing the area so as to produce the highest possible benefit while, in turn, preserving the integrity of the nature, the culture, and the traditions that characterize the zone $[1,15,40]$. It is a complicated challenge, above all when having to administer the interactions between an environment to be protected and its visitors [40]. Even more so due to the number of interest groups involved, including actual and potential visitors, commercial allies, non/visitors, local communities, political institutions, and organizations for protecting the environment, among others $[16,40,41]$. Bearing those stakeholders in mind, the local community may feel threatened by the mass presence of tourists [41]. Cooperation with the environment and the search for synergies between local community and NP are fundamental. When the inhabitants of a place feel considered and involved in the development phases of tourism, it will be better accepted [42]. This coordination of effort between representatives of NPs and affected communities is fundamental for the success of the marketing plan that seeks to convey the distinctive characteristics of the park [43].

With reference to the visitors, other authors have identified the importance of creating relations of loyalty with them based on trust and commitment [44]. This incorporation should also be done through marketing, promotion and communication. Hence the affirmation of Bitsani and Kavoura [41] that the actions set into motion will in this way be more organized and will yield better results.

Thus, the satisfaction of different interest groups is a fundamental aspect in the application of marketing, which should develop the capability of managing user relations and interests, visitors or otherwise, and local communities through a proactive approach [40]. This is in line with the latest definition of marketing from the American Marketing Association (AMA) [45], which places an emphasis on value creation in the exchange for all interested parties [46] and a more committed perspective towards the values that Kotler et al. [47] proposed, including, quite naturally, environmental conservation $[24,40,48]$.

Given this complexity, the managers of the parks will need specific and very concrete skills to operate in an environment of uncertainty, conflict and complexity, which is characterized by the pursuit of that twin and apparently contradictory objective [49]. This complexity may be approached through an ethical marketing perspective being applied to the environment. Following the model of Hunt and Vitell [50], ethical opinion is formed through two (deontological and teleological) assessments and 
determines the antecedent intentions to behaviour. Knowledge of how that opinion is formed and the intentions necessary to foresee it and to act in consequence is a branch of marketing research known as macromarketing [22,23] or, more specifically, environmental marketing [15,17].

The management of NP marketing can contribute various benefits: (1) the reduction of the management costs, as an essential role is played in sustainable development and preservation of ecosystems [1,51]. The results of the study of Corbera et al. [51] recognize that marketing has a fundamental role in increasing the benefits arising from effective management, increasing the overall economy of protected zones. (2) Marketing has a positive effect, as it delimits the creation of the natural destination, through a name, a logo, some words (catch phrase) and a design associated with the values of the park [52], or through an identifying image [52,53]. (3) Marketing adjusts the service to the needs and redirects efforts towards clearer and more defined objectives. This is made possible through the use of satisfaction surveys of the different groups of stakeholders [40,54]. Likewise, the application of segmentation, a fundamental tool for marketing strategy and planning [3], as well as benchmarking for the management of NP.

Marketing theory itself has evolved over time to focus on the concept of sustainability. First, ecological problems emerged as a new paradigm in marketing strategy. Second, social problems emerged alongside ecology. Third, marketing started to focus on environmental problems, and finally, sustainability in the marketing strategy has now become the focus of attention of researchers $[55,56]$.

In the field of tourism and NP management, two marketing strategies have been developed [57]: the development of Corporate Social Responsibility (CSR) within the company itself, and carrying out marketing actions to influence the visitors, so that visitors will have a sustainable behaviour. However, new approaches addressing other agents are necessary, such as managers themselves, to know what knowledge or techniques to promote the development of sustainable marketing [58].

In NP tourism, the so-called "experience economy" plays a fundamental role [59], which arises from a general need to develop the individual identity and acquire personal experiences in accordance with values and beliefs with respect to a deeper relationship with nature [60]. The management of natural spaces should offer its visitors the value associated with sustainability with coordinated communication from top management [39].

However, when it is there, the application of marketing is neither always correct nor free from controversy, as in the following cases.

There is a lack of directives on the correct use and implementation of marketing techniques in the management plans of NPs [49]. Small efforts to conduct marketing for NPs has given way to their passive promotion, which implies a weakness [52].

A very weak effort is detected, which is evident from scarce financing, because of the bureaucratic and political pressures to which these zones of collective interest are subject $[61,62]$. Thus, the managers of NPs have little room for manoeuvre when implementing actions that would be of benefit to the park $[1,15]$. Another important handicap is the training and the personal characteristics of the directors. Although there are those in favour of using marketing techniques [63] whose actions in NPAs have not gone uncriticized [17], there are also those who think that "sustainability" and "marketing" can live happily with one another [64], certainly because of a biased interpretation of the concept of marketing. More information is needed and more training to eliminate the stigma of marketing and to raise awareness of it as an effective and useful instrument for the protection of the fragile ecosystem [1]. According to Leverington et al. [32], $42 \%$ of NPAs lack fundamental aspects of management, while $13 \%$ showed true weaknesses, above all in relation to the topic of communication.

Another of the principal problems of management is the lack of relevant messages and communication $[1,52]$. These weaknesses are serious because they detract from the contribution of NPAs to their environments $[65,66]$. Communication is a great weakness, due to the lack of information and, in general, a communication strategy. It is necessary to identify expectations before it is possible to respond in a satisfactory way, increasing the congruence between the expectations and the experiences lived in the park [67]. The quality and the amount of information in our era coupled 
with easy and instantaneous access to it are the keystones of both good marketing strategy and good client services [68]. The communication of NPs must have a content that reflects the commitment of sustainability and awareness among its potential audiences [69,70].

Standard techniques in marketing such as segmentation and benchmarking have not found widespread use among the directors of NPAs [71,72]. The implementation of these tools, as well as being pertinent, should be performed by experts [40], given that proper staff training and preparation regarding the carrying out of all marketing management-related tasks are very important aspects [24]. For effective management, directors of NPAs should know how to quantify the benefits that the park provides to its visitors, such as leisure and free time and the continuity of their existing biodiversity [28]. The majority of directors are prepared to respond to environmental questions, but this is less so regarding tourism and marketing [52].

This all means that, at times, the local communities are not committed and see themselves as being excluded from possible benefits [51]. As Donohoe [49] recalled, rather than a stigma, the application is a great opportunity for the promotion of these enclaves and for their benefit.

In the context of this reticent application of marketing and with all of these difficulties, our aim is to gather the opinions of NP directors on how marketing may be applied; in brief, to conduct a marketing audit of NPs and to study their behaviour on social media.

\section{Methodology}

The Importance-Performance Analysis (IPA) matrix introduced by Martilla and James [73] will be used to conduct the marketing audit. This is a useful and reliable tool for measuring the management of tourism destinations in general, as well as products and services [54]. It adopts an expectations-performance approach to measure perceptions of quality. The IPA matrix is likewise usually helpful for arriving at strategic decision-making directives for marketing, as it is used to evaluate different aspects of organizational characteristics in terms of perceptions of performance and the importance of results, facilitating the prioritization of improvements, and the mobilization and deployment of scarce resources where they are most needed [74]. The matrix gives us insight into both strong and weak points for service improvement. The IPA matrix has been widely used in the marketing literature as a basic diagnostic decision tool [26].

In short, IPA is applied because it makes it possible to register the managers' perception of what they consider more or less important in the application of marketing and what they consider better or worse implemented in the performance of marketing, therefore allowing the identification of large deficits in the application of marketing. As this is the objective being pursued, IPA is the right tool.

According to [75-79], the process of applying the IPA matrix has the following steps [80]:

(1). Determine the problem or challenge: perform an internal marketing audit in the NP sector;

(2). Concretize the objective: from a practical and management point of view, know the strengths, weaknesses and deficits in the application of marketing in the NPs sector, following the analysis of the IPA quadrants. From a methodological point of view, the purpose is to apply a new form of validation: the application of the ROC curve (Receiver Operating Characteristic);

(3). Selection of items: the appropriate items have to be selected to obtain the best possible application of marketing for NPs. On the basis of the proposal of Kotler and Dubois [81], 83 items were prepared and grouped into six dimensions, related to the surrounding environment, strategy, organization, system, productivity, and functions. The items were assessed by 4 marketing experts in the framework of the Delphi model. After the first assessment, each expert had access to the average score of each item (on a scale from 1, of little importance, to 10, very important), before moving on to the second vote. The items with the highest average scores for importance and the lowest standard deviation were selected. Finally, the questionnaire was formed of 32 items, grouped into the six aforementioned dimensions, which are listed in Appendix A. We analyse the adequacy of marketing management from the point of view of managers, directors and representatives of the NPs. Therefore, 
it is expected that the results for all the items would suggest them to be very important, and the difference being the self-perceived deficit in the marketing application;

(4). Measure: this was carried out by obtaining direct data. All items were measured on a Likert scale from 0 to 10 points. To do this, the indications of Alpert [82] and Bacon [75] were followed. In accordance with these authors, direct measurements better reflect the attribute than indirect methods. Direct gradings are more stable and valid, and better reflect the importance of the attribute compared to indirect measures $[76,83]$.

(5). Validation: this was carried out through the application of the ROC curve. According to Server [78], this is able to provide the criteria for an optimal categorization of the elements in the framework of IPA.

The study aimed to have a multi-country perspective from different continents. This is why two European countries (Spain and Italy) and two American countries (USA and Mexico) with long traditions in national park management were selected. All the NPs that appear in the official lists available from those countries were contacted. Finally, 41 NP managers responded. 55\% were general managers of parks, and the rest were department directors or other managers. $20 \%$ of respondents belonged to national parks, and the rest belonged to natural parks and similar protected contexts. The vast majority belonged to Spanish parks ( 31 parks), followed by Mexico with 6 parks, while in the USA and Italy there were 2 parks in each country. It is not easy to get a high response rate for this type of population (managers), in this type of institution (parks) in different countries. However, for studies with these characteristics, regarding the positioning of perceptions, it is not necessary to have a big sample to obtain an acceptable representation of the situation.

The details of the field work are summarized in Table 1. The population under study comprised natural areas of Spain, Italy, USA, and Mexico, the directors of which were sent a URL via e-mail to respond to an online self-administered questionnaire (32 items for each one of the two dimensions: the situation of their NP with respect to each item and the importance it had for the development of the NP). The Qualtrics platform was used for the management of the questionnaires. The field work was conducted between the months of November 2017 and January 2018. Convenience sampling was applied, to which 41 directors and technicians responded. The great majority were from Spanish areas (31).

Table 1. Summary of the marketing audit field work.

\begin{tabular}{cc}
\hline Characteristics & Natural Protected Areas \\
\hline Universe & Spain, USA, Italy and Mexico \\
\hline Sampling method & Convenience sampling \\
\hline Num. responses & 41 \\
\hline Date & 10 November 2017-10 January 2018 \\
\hline Num. of Items & 32 (for the 6 dimensions) \\
\hline Survey platform & Qualtrics. Self-administered online survey \\
\hline
\end{tabular}

Additionally, secondary data were used to analyse social media network activity by selecting 15 areas of the USA, Spain, and Italy, and 14 from Mexico. The indicators were taken from their activity on Facebook (15 indicators) provided by LikeAlyzer and on Twitter (11 indicators) provided by Foller, as shown in Table 2. 
Table 2. Characteristics of the study for the analysis of social networks.

\begin{tabular}{cc}
\hline Characteristics & Protected Natural Areas \\
\hline Universe & 15 NPA of USA, Spain, Italy and 14 Mexico \\
\hline Source & For Twitter: Foller \\
& For Facebook: LikeAlyzer \\
\hline Date consulted & 19 November 2017 \\
\hline Num. of Indicators & For Twitter: 12 \\
& For Facebook: 15 \\
\hline
\end{tabular}

The indicators from Twitter are shown in Table 3 and those of Facebook in Table 4 .

Table 3. Twitter indicators (Foller).

\begin{tabular}{|c|c|}
\hline Indicator & Description \\
\hline Tweets & Total number of tweets created. \\
\hline Followers & Total number of followers. \\
\hline Following & Total number of followers. \\
\hline Followers per following & Ratio between followers over pages following. \\
\hline Listed & Total number of lists on which the account can be found. \\
\hline Replies & $\begin{array}{l}\text { Total number of responses to tweets from followers. This indicator is measured on } \\
\text { the basis of } 100 \text { tweets. }\end{array}$ \\
\hline Tweets with@mentions & $\begin{array}{l}\text { Total number of tweets mentioning the account. This indicator is measured on the } \\
\text { basis of } 100 \text { tweets. }\end{array}$ \\
\hline Tweets with \#hashtags & $\begin{array}{l}\text { Total number of tweets with hashtags. This indicator is measured on the basis of } \\
100 \text { tweets. }\end{array}$ \\
\hline Retweets & Total number of retweets. This indicator is measured on the basis of 100 tweets. \\
\hline Tweets with links & $\begin{array}{l}\text { Total number of tweets containing links to other accounts. This indicator is } \\
\text { measured on the basis of } 100 \text { tweets. }\end{array}$ \\
\hline Tweets with media & $\begin{array}{l}\text { Total number of tweets with multimedia content. This indicator is measured on } \\
\text { the basis of } 100 \text { tweets. }\end{array}$ \\
\hline
\end{tabular}

Table 4. Facebook indicators (LikeAlyzer).

\begin{tabular}{|c|c|}
\hline Indicator & Description \\
\hline FrontPage & $\%$ efficiency of the FrontPage. \\
\hline About & $\%$ amount of additional information provided. \\
\hline Activity & $\%$ level of activity. \\
\hline Response & $\%$ of responses from the page to posts from its followers. \\
\hline Photos & $\%$ of photos posted. \\
\hline Videos & $\%$ of videos posted. \\
\hline Notes & $\%$ of notes posted. \\
\hline People talking about this PTA & Num. of people who have interacted with the page over the last 7 days. \\
\hline Total Page likes & Total "likes" that the page has received to date. \\
\hline Engagement rate & $\begin{array}{l}\text { \% commitment of its followers on the page; calculated by dividing the } \\
\text { number "People talking about this" by the total of all "likes". }\end{array}$ \\
\hline Posts per day & Average posts by day sent from the page. \\
\hline Average post length & Average extension (in characters) of a post created by the page. \\
\hline Events & Number of events created by the administrators. \\
\hline Pages liked & Number of "likes" given by the page to other pages. \\
\hline Native Facebook videos & Total number of videos created and directly posted. \\
\hline
\end{tabular}




\section{Results}

\subsection{Marketing Audit}

The analysis of the items in the IPA matrix was done by applying non-parametric tests (the Wilcoxon and the Mann-Whitney tests) for the separate items and testing whether there were significant differences between importance and performance for each one.

One third of the characteristics that were considered most important, with scores of 7.79 to 9.23 over 10, with an average score of 8.38 (Appendix A), had to do with the analysis of the surrounding area (taking into account the principal economic events in the area, seeking sustainable alternatives related to environmental impact, understanding visitors' opinions and responding to legislative change); with the marketing strategy (formulating the mission with clarity, feasibility and transparency, using a corporate identity manual, encouraging good relations with the interest groups, and use of Internet all form part of that strategy); the organization of marketing (clearly defining employment positions with objectives, responsibilities and sufficient authority); and functions (website that was accessible and well-positioned in search engines, and a reliable system of internal communication). See Appendix A for information on the items of each dimension.

With regard to those considered to be of lesser importance, the lower scores were linked to internal human resources (training and motivation of employees, relation between departments), knowledge of their public and of other NP, the completion of direct and online marketing activities, and web analytics and communication.

According to the directors, a third of the items that presented a high assessment of performance-in other words, those that were done best (scores between 6.33 to 8.36 over 10, the average of the third best score of 7.14, Appendix A, Table A1) - had to do with taking into account, in relation to the natural area, the principal economic events; seeking sustainable alternatives to environmental impact; knowing the opinions of their visitors; and knowing and responding rapidly to changes in legislation that might affect them. With regard to strategy, what was done best was related to clear definitions of the mission, which has to be feasible and known to everybody; having a corporate identity manual; and encouraging good relations with interest groups and the internet as part of the strategy. With regard to organization, the best actions related to positions of employment and sufficient authority; and, finally, with regard to functions, the availability of an internal communications system, and "services and characteristics of the park present some added value that differentiates them from others".

On the contrary, the lower third of the worst valued characteristics of principal weaknesses, with scores of below 4.5 over 10, and with an average score 3.52 in the lower third, with regard to the natural area, were as follows: availability of a coherent and feasible marketing plan, and seeking new unsatisfied segments; in organization: training in the subject matter and staff motivation; in systems: control over the achievement of marketing objectives and the use of web tools for analytics; in productivity: studying the social impact of their services and reviewing the cost of marketing activities. Finally, with regard to functions: periodic reviews of tourist operators, completion of marketing activities and integration of communications.

The scores for importance were higher than those for performance, with statistically significant (or quasi-significant) differences, apart from some exceptions. Those exceptions were the situations in which there was no great imbalance in the scores; in other words, performance was considered to be practically at the same level as importance, as in the consideration of the internet as a part of park strategy, the search for sustainable alternatives relating to environmental impact, a clear definition of the mission, and the availability of an internal communications system. Neither were there differences, although their scores were lower than the earlier ones, for the items relating to training in marketing, and the completion of an online database and direct marketing activities (Appendix A, Table A1).

The difference between importance and performance (or assessment) yielded an average score for the existing deficits. The items relating to the two dimensions of environment and marketing strategy were predominant, both for importance and for performance, being in the upper third with higher 
scores, while the opposite was true for the other dimensions, in particular for systems and organization (Table 5).

Table 5. Distribution of the items of each dimension in the higher third (+), intermediate $(=)$ and lower third (-) of scores for each one of the blocks.

\begin{tabular}{cccccccccc}
\hline \multirow{2}{*}{$\begin{array}{c}\text { Dimensions } \\
\text { (Num. Items) }\end{array}$} & \multicolumn{3}{c}{ Importance } & \multicolumn{3}{c}{ Performance } & \multicolumn{3}{c}{ Differences } \\
\cline { 2 - 10 } & + & $=$ & - & + & $=$ & - & + & $=$ & - \\
\hline Environment (7) & 4 & 2 & 1 & 4 & 3 & & & 2 & 5 \\
\hline Strategy (8) & 4 & 3 & 1 & 4 & 2 & 2 & 2 & 3 & 3 \\
\hline Organization (4) & 1 & & 3 & 1 & 1 & 2 & 2 & 2 \\
\hline System (2) & & & 2 & & & 2 & 2 & & \\
\hline Productivity (3) & & 2 & 1 & & 1 & 2 & 2 & & 1 \\
\hline Functions (8) & 2 & 3 & 3 & 2 & 3 & 3 & 3 & 3 & 2 \\
\hline Total & $\mathbf{1 1}$ & $\mathbf{1 0}$ & $\mathbf{1 1}$ & $\mathbf{1 1}$ & $\mathbf{1 0}$ & $\mathbf{1 1}$ & $\mathbf{1 1}$ & $\mathbf{1 0}$ & $\mathbf{1 1}$ \\
\hline
\end{tabular}

When distinguishing between importance and performance (column of differences), the least differences were found for items related to the dimensions of environment and strategy. Meanwhile, the highest scores were attributed to the dimensions of organization, system and productivity; the items for the dimension functions were distributed between the categories of greater, lesser, and no differences, and the least differences were found for environment and strategies. The highest deficits were given for all items of marketing systems (control the achievement of offline and online marketing objectives and evaluate the shortcomings, use web analytics tools), with the most being for productivity (periodically studying social impact that it provokes, periodically revising the costs of marketing activities); and organization (training of those participating in marketing activities, motivation of those participating in the pursuit of marketing activities); with some strategy-related items (availability of a coherent and feasible marketing plan, taking account of the proper tourism load in the marketing strategy); and functions (periodically reviewing the effectiveness of tourism operators, complete direct, online and database marketing activities, integrated communications into marketing). None of the items of the environment dimension were among those with the highest deficits.

There is, moreover, a high coincidence when assessing both items of performance and of importance between top directors and other park representatives. Their assessments coincide, and significant differences were only recorded, in accordance with the Mann-Whitney test, for the assessment of performance in training, and in staff motivation, the use of web analytics and the review of costs. In all these cases, the lower assessments corresponded to the executive directors, who were more critical of these deficits.

A first analysis of the representation of IPA shows all the items. In quadrant 1 are the items of greater importance and greater performance, and in quadrant 2 are found the items that are of high importance but lower performance, i.e., the weaknesses.

According to [77-79], in particular Luque et al. [80], for a more detailed analysis of the graphic representation of IPA we proceed as follows:

(1). Calculate the average values of performance, importance, and their difference as a measure of the self-perceived deficit in the application of marketing management to NPs;

(2). When it comes to applying the IPA to consumer satisfaction, according to the theory of disconfirmation, if the performance-importance difference is zero or positive, there is satisfaction, while there will be dissatisfaction if it is negative. In the current case, a zero or a positive difference is considered a sufficient application of marketing management, while if it is negative, it will be a poor application; 
(3). Identification of the performance-importance thresholds (or crossing point), to delimit the quadrants and to identify which items are in each one. To do this, we calculate the probability (sensitivity) that a great difference between performance and importance (a great deficit) is considered to be a weakness or insufficient application of that characteristic. A probability (specificity) that a small difference would not be considered a weakness is also assumed; in other words, a sufficient application is considered. The ROC curve gives information for all combinations of sensitivity and specificity. The closer you are to the diagonal, the less suitable the combination is; the farther away, the more appropriate;

(4). Validation by measuring the power of discrimination of the ROC curve and the Youden test [84]. The power of discrimination of the ROC curve is the area under the ROC curve (AUC); in other words, the probability that the value of the diagnosis is greater than that randomly selected with a positive result rather than with a negative result. The value of 0.5 means that accuracy is equal to a random chance, while a value of 1 means higher accuracy. In our case, the performance has an AUC value of 0.91 , which is very good. According to importance, the discriminatory power is poor (0.78), but also good; managers discriminate a lot in terms of the performance and the importance of the selected items. Youden's test provides a measurement of importance considering sensitivity and specificity for every point of the ROC curve. Youden's test is equal to sensitivity plus specificity minus 1. The point to choose is the higher one. For performance, the highest value of Youden's test is 5.765 ; for importance, it is 7.735 . The average values are 5.37 for performance and 7.24 for importance.

Figures 1 and 2 show a representation using the highest values of performance and importance for the test of Youden the cut-off.

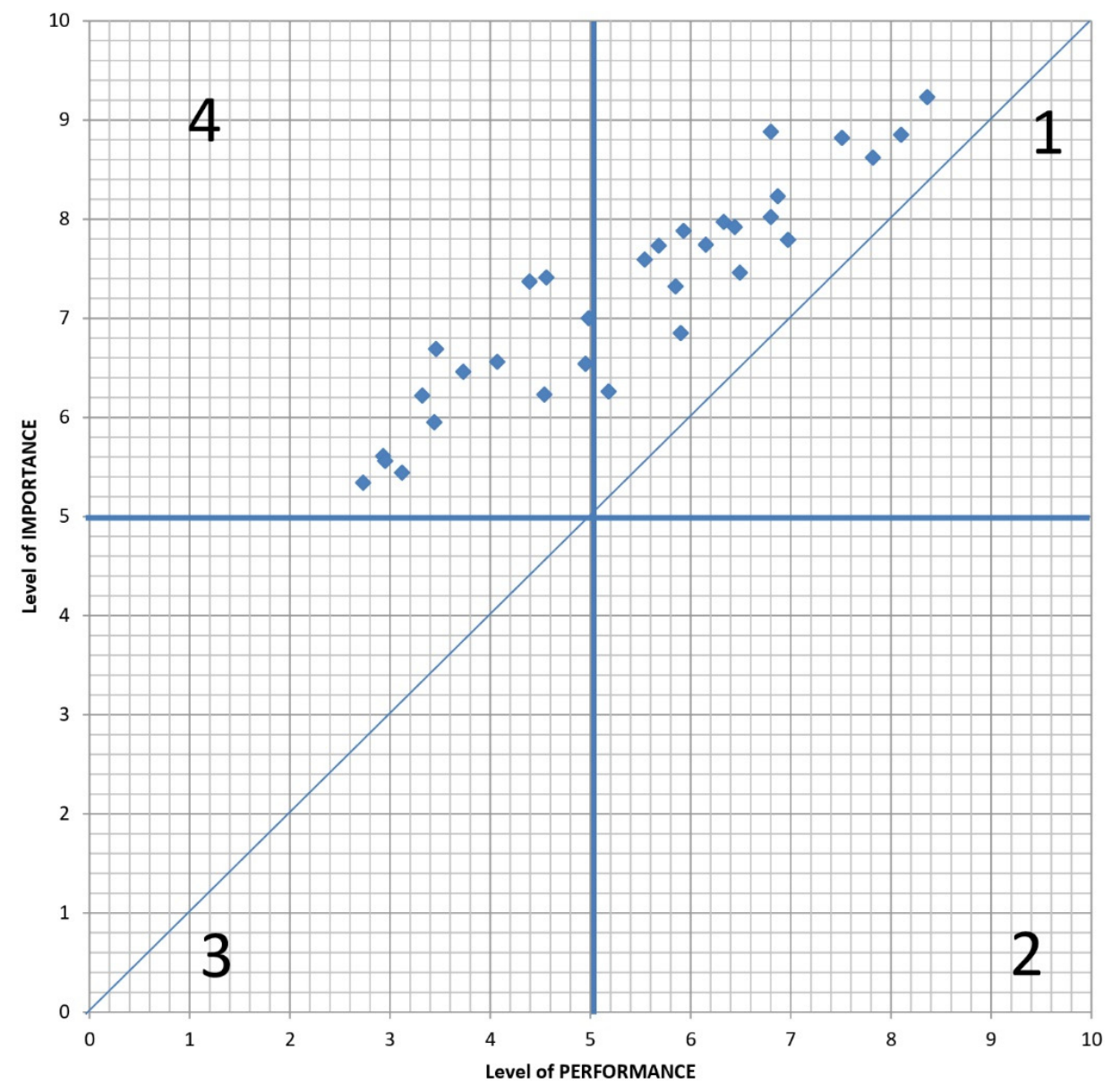

Figure 1. Importance-performance analysis matrix. 


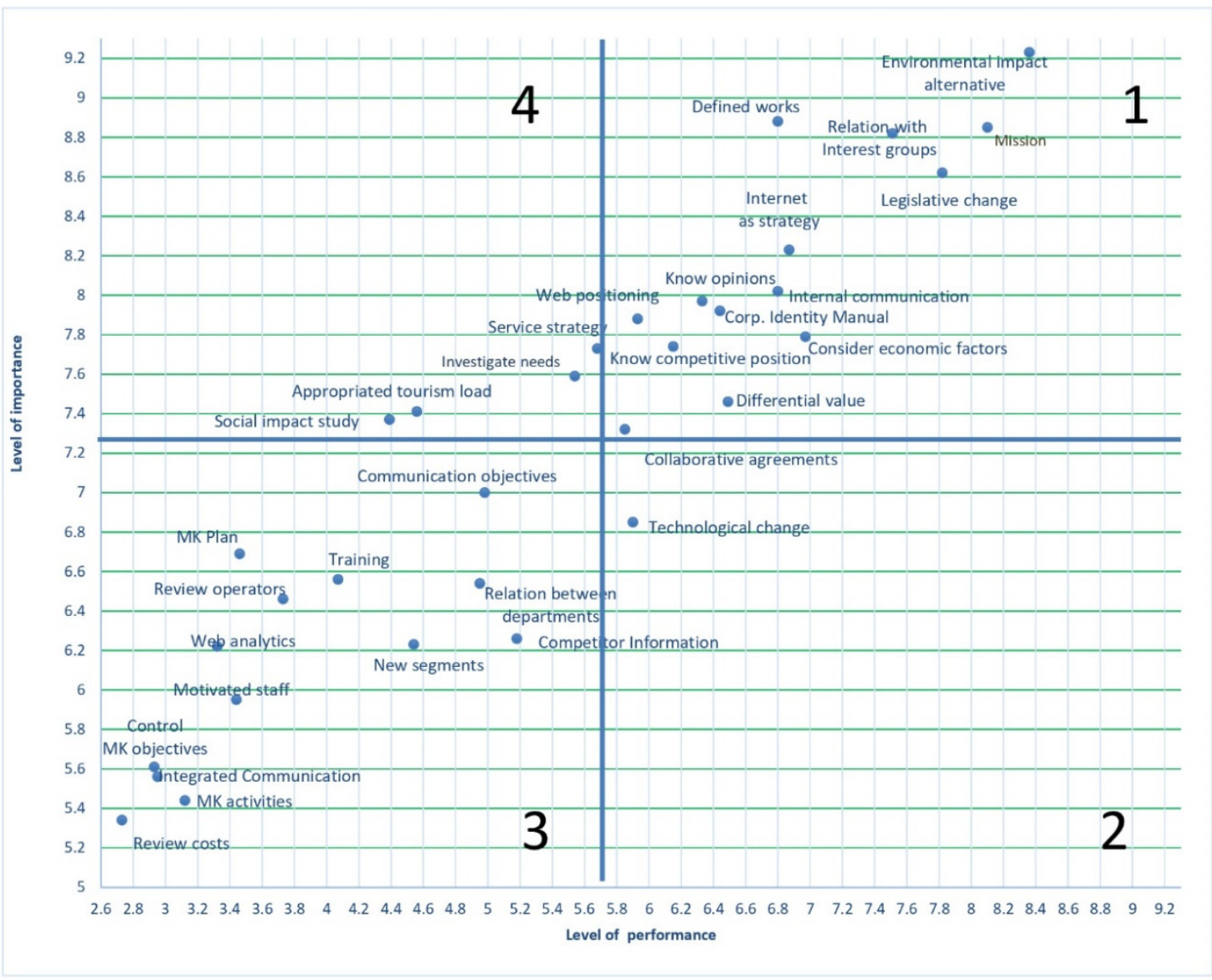

Figure 2. IPA taking into account sensitivity and specificity.

In this way we obtain a new cut-off, shown in Figure 2, with a new scale, allowing the details to be interpreted easily. The aspects that are performed especially well (quadrant 1, Figure 2), according to Natural and National Park managers, are those that have to do with the dimension of "marketing setting" (takes into account the principal economic events of the business setting before taking action; seeks sustainable alternatives relating to environmental impact; the park knows the opinion of its visitors, real and potential, and it knows and replies quickly to changes in the legislation that affects it) and "marketing strategy" (the mission statement is clearly worded, is feasible and known by all members of the organization; it has a manual of corporate identity; the strategy of the park emphasizes a good relation with its interest groups, the strategy of the park emphasizes a good relation with its interest groups; Internet forms part of the marketing strategy of the park; the park knows its competitive position, its threats and opportunities, to define objectives). In this quadrant, there are also three items of "marketing functions" (web positioning; internal communication systems; services with added value) and one item of "organizations" (employment positions defined with objectives, responsibilities, and authority to carry them out).

On the other hand, quadrant 4, Figure 2 shows the aspects of marketing with the most deficient application in the NPs, that are the study of the needs of its objective public; to take into account a balanced tourism load for the park; to study periodically the social impact that can provoke; and to define clearly its strategy on the quality of services.

Most of the rest of the aspects (quadrant 3, Figure 2) do not have a high performance and are not considered as high a priority as the previous ones. These aspects are mainly related to the dimensions of "organization of marketing", "marketing systems" and "marketing functions".

For managers, there are many aspects of marketing application that have a rather low performance. 


\subsection{Analysis of the Social Media Networks of the NPA}

\subsubsection{Twitter}

With regard to activity on social media, and beginning with Twitter, it was confirmed that not all the parks that were selected had an account on this social network. All of the parks in the USA and Italy and the majority of the parks in Spain, but only 4 of the parks selected in Mexico, used Twitter, for which reason the comparison by countries is not included.

Statistically significant differences were confirmed by the Mann-Whitney test. The Twitter activity of the parks in the USA was much higher than in the other countries. The parks in the USA had a much higher number of followers than the Italian parks (67 times more), a greater ratio of followers/pages following (347 times higher), lists in which they figure (18 times more), replies to tweets from followers (over 8 times), and a total number of tweets with multimedia contents (2.35 times more).

In comparison with the Spanish parks, those of the USA had (48 times) more followers and a higher ratio of followers/pages following (156), appeared in (16 times) more lists, and replied more to followers (5.5 times). In contrast, the Spanish parks had double the total number of tweets with hashtags and number of retweets of parks in the USA.

The NPs of Spain exceeded Italy in all Twitter indicators (except for the number of followers). On average, they sent more tweets, they had more followers, more lists, more replies, more tweets with hashtags, but all without statistically significant differences. There were only significant differences in the number of tweets with multimedia content: the Spanish parks had more than the Italian ones.

\subsubsection{Facebook}

With regard to Facebook, there were statistically significant differences in 12 of the 15 indicators under analysis, according to the non-parametric Kruskal-Wallis test (Appendix A, Table A2). The majority of indicators were in the following order (from higher to lower values): USA, Italy, Spain, and Mexico. This is the case of the indicators about, activity, average_post_length, events, pages_liked, PTA, total_pages_liked. The parks in the USA provided remarkably more information, had more activity, a greater extension in their posts, created more events, received and sent more "likes", and interacted more frequently. In brief, they were the most dynamic on Facebook, and made proactive use of this network. The Mexican parks were found at the opposing extreme. That order was not strictly followed in the other indicators, where there was some variation. Thus, the Mexican parks moved into second place for photos, the US parks were followed by the Spanish parks in "posts per day", and the Mexicans were in front of the Spanish in "native FB videos".

However, the sequence from most to fewest numbers of "notes" was totally different. The Italian parks were first, and the United States came last. Meanwhile, the Mexican parks came in first place for "engagement rate", due to their lower level of interaction.

\subsection{Cluster of NPA According to Twitter and Facebook Indicators}

The values were standardized to identify the clusters of parks in accordance with their performance in each of the social networks. After applying different hierarchical grouping procedures, such as the Ward method and the complete linkage method, with different types of distance, it was concluded that the most suitable cluster would be formed of five groups. Having decided on the number of groups, the $\mathrm{k} /$ means option of the cluster analysis yielded the results shown below (see Table 6). 
Table 6. Clusters identified by Twitter and Facebook indicators.

\begin{tabular}{|c|c|c|c|c|c|}
\hline Cluster & Low Profile & Moderately Active & Leader & Followers & Inactive \\
\hline Tweets & -0.154 & 1.098 & 0.893 & 0.028 & -0.409 \\
\hline Followers & -0.318 & 1.33 & 3.522 & -0.263 & -0.316 \\
\hline Following & -0.634 & 0.113 & -0.826 & 0.523 & -0.46 \\
\hline Followers/pages following & -0.169 & -0.035 & 6.236 & -0.171 & -0.176 \\
\hline Listed & -0.497 & 1.818 & 3.12 & -0.228 & -0.459 \\
\hline Replies & -0.366 & 0.19 & 4.971 & -0.176 & -0.138 \\
\hline Tweets with @mentions & -0.277 & 0.002 & 0.918 & 0.152 & -0.185 \\
\hline Tweets with \#hashtags & 1.787 & -0.413 & -1.13 & 0.294 & -0.336 \\
\hline Retweets & -0.413 & -0.216 & -0.742 & 0.247 & -0.097 \\
\hline Tweets with links & 1.027 & -0.063 & 0.472 & 0.547 & -0.72 \\
\hline Tweets with media & -0.364 & -0.331 & -0.689 & 0.14 & 0.044 \\
\hline Frontpage & 0.626 & 0.626 & 0.626 & 0.507 & -0.559 \\
\hline About & 0.59 & 0.617 & -0.3 & 0.582 & -0.54 \\
\hline Activity & 0.241 & 1.173 & 0.448 & 0.764 & -0.761 \\
\hline Response & 0.723 & 0.32 & 0.723 & 0.173 & -0.265 \\
\hline Photos & 0.514 & 0.953 & 0.704 & 0.147 & -0.342 \\
\hline Notes & 0.393 & -0.512 & -0.279 & 0.499 & -0.301 \\
\hline Videos & -0.248 & 0.015 & 0.561 & 0.743 & -0.562 \\
\hline Posts per day & 6.869 & 0.361 & 0.305 & 0.072 & -0.375 \\
\hline Average post length & 1.627 & 0.267 & 0.493 & 0.471 & -0.535 \\
\hline Events & -0.15 & 0.056 & -0.297 & 0.579 & -0.423 \\
\hline Pages liked & 0.509 & 1.416 & -0.364 & 0.439 & -0.605 \\
\hline Native Facebook videos & -0.699 & 1.625 & 2.345 & 0.423 & -0.641 \\
\hline PTA & -0.448 & 2.201 & 3.784 & -0.136 & -0.394 \\
\hline Total Page likes & -0.436 & 2.169 & 3.541 & -0.07 & -0.43 \\
\hline Engagement rate & -0.091 & -0.034 & 0.003 & 0.03 & -0.009 \\
\hline
\end{tabular}

Bold: highest values among the different clusters. Italic: lowest values between the different clusters. Shaded: No significant differences.

Group 1: Low profile on social networks

The indicators of this group were very low for Twitter: lower numbers of followers, presence on lists, and number of replies. These parks had some of the lowest numbers of followers and followers/pages following ratios. However, they had a higher number of tweets with hashtags and links. The group was more active with regard to Facebook, above all because of the average number of posts per day, their extension, and the effectiveness of their front page. However, they showed limited production of their own videos, stimulated few conversations, and received few "likes". This was a group comprising two Spanish parks, which are special cases: the Marítimo Terrestre Cíes NP and Teide NP.

Group 2: Moderately active in social media networks

Parks with a higher number of tweets, but without standing out in other ways, due to neither excess activity nor to low activity. This group stood out in Facebook because of additional information on its webpage, the level of activity of the page, the percentage of photos posted and the "likes" that they received, but not because of the percentage of notes. It is a social network profile that might be described as one of maintenance. It numbered five groups, all from the USA.

Group 3: Leadership

This group was second in terms of number of tweets, and stood out especially because of its high number of followers, the small number of pages followed, the high ratio of followers/pages following, 
and the number of lists in which they appear. This group also had the lowest number of tweets with hashtags. It was also the most active on Facebook, the one that replied most to messages, posted the most videos, broadcast more of their own videos, clearly generated more conversations, and received more "likes". It was clearly a leadership behaviour, and a reference point in social networks. This group consisted of only one park: Yosemite National Park.

Group 4: The follower

This group stood out only because of the number of followers and the low ratio of followers/pages following. Its only remarkable differences on Facebook were the events created and the percentage of notes; it occupied intermediate positions in relation to the other indicators. It appeared to be a follower in social media communications and was a numerous group that included 21 parks, the majority Italians $(60 \%)$, with quite a few from the United States (42.9\%).

Group 5: Inactive

This group only stood out due to its low values in comparison with the rest. A lower number of tweets of followers/following, lists in which it appears, and tweets with links. On Facebook, this cluster includes the parks with the lowest of all indicators. It is a very low activity profile, associated with little pro-active communication in response to beginners or people who do not engage in social network communication. It was the most numerous group, comprising 30 parks, most of which were Mexican parks (80\%), the majority of Spanish parks (66.7\%), some Italian ones (40\%) and a few from the USA (14.3\%).

Groups 4 and 5 had the most similarities, while groups 1 and 3 differed more than any other.

\section{Discussion}

Conservation and management are two terms that need to be reconciled. It is a dilemma, the difficulty of which increases with the number of agents that become involved $[1,15,40,41,49]$. The concept of marketing awakens mistrust in some of those in charge of NPAs, as the literature has shown; however, marketing has a lot to contribute, in so far as it concerns itself with the management of expectations, relations and communications between stakeholders [42-44]. Numerous studies have highlighted important weaknesses in the application of marketing techniques, and in the communication that takes place in NPAs. This situation justifies the need to look in depth at the diagnosis and to propose actions for improving the management of marketing and communication in these organizations, from an ethical marketing and macromarketing perspective [23,50].

A marketing audit of Natural and National Parks (NPs) in four countries was conducted for a complete diagnosis [81], through a questionnaire administered to directors and representatives of the parks; their behaviour on the two of most well-known social media networks was then analysed.

A first methodological type of conclusion has been reached, showing the incorporation of the marketing audit concept and the use of IPA matrices for the diagnostics, as well as the use of activity indicators on social networks for the analysis of communication in NPs.

Another previous conclusion, highlighted during the field work, was that a portion of the directors and representatives expressed a restricted, limited, and biased concept of marketing, almost associating it with pressure sales. Moreover, confirmation of reticence toward the application of marketing in NPs. All of that is highlighted in the communication maintained during the field work with such expressions as "we do not sell", "we do not compete", "we need to increase the number of visitors". The inclusion of marketing actions does not necessarily have to be oriented towards such objectives, as it can also be focused on informing, and raising consciousness, understanding and education for the visit, as well as attempting to ensure visits are distributed to avoid peaks of saturation.

The analysis of the IPA matrix shows that the most important among the marketing audit items were those items linked to the dimensions of environment and strategy. As was expected, greater importance was attached to strategic aspects than to the day-to-day management or operation. 
In general, that assessment coincided with the assessment of performance. On the contrary, the worst performances, and therefore the weaknesses, were linked to marketing planning, staff training and motivation, the follow-up process, control over objectives and costs, the study of the social impact of NP, and the completion of direct and online marketing and communication activities. Those weaknesses refer to aspects considered very important, as well as to others that are not regarded to be so important.

The weaknesses in the very important questions reveal great deficits which, in the first place, are related to the planning of marketing and the completion of direct and online marketing activities, including control and follow up of costs and achievement of marketing objectives and taking account of web analytics. In second place, the need to conduct social and economic impact studies, taking into account the tourist load of the NP in the decisions and periodically review the actions of tourist operators. In third place, a staffing policy that contemplates the formation and motivation of people working on marketing content. Finally, to improve communication, in particular so as to achieve much more integrated communication in all activities both on and offline.

With regard to communication in social networks, a great difference has been noted in the activity on Twitter between the NPA of the four countries. Those in the USA are more active and have a more proactive behaviour on this social network, which they incorporate into their communicative strategy. The Spanish and Italian NPs follow, and some distance behind, with much less activity, we find the Mexican NPs. On Facebook, the communication activity of the NPs in the USA is by far the greatest, followed by those of Italy, Spain and Mexico, in that order, for the majority of indicators.

Five profiles were identified for these social networks: low, moderately active, leadership, follower, and inactive. There were significant differences by countries, with those of Spain and, especially, of Mexico being the least active, compared with those of the USA, who were the most active, leading communicationy in those social networks.

The recommendations arising from the above all point to the need to implement marketing planning from its preliminary investigation (incorporating web analytics and general digital marketing actions) through to implementation (in marketing activities in the integration of communication actions) and, of course, follow-up and control of objectives and costs. This planning should be sensitive and in coordination with the impact studies of the NPs, reviewing and analysing the tourism load and the relations with the different agents related to the NP. Communication with stakeholders should be taken care of, and (on- and offline) actions should be integrated and coordinated. Finally, another recommendation is to establish training plans and staff motivation that develops marketing activity, from the perspective of ethical and macromarketing. In brief, this study can serve to establish priorities and a working method of marketing for NPs.

From the point of view of visitors and directors, the results obtained contribute to the development of so-called eco-prosumption [85]. This is the manner in which value is produced and consumed in a socially and environmentally responsible manner, both by visitors and by the managers of natural spaces.

In this study, behavioural patterns on Twitter and Facebook were also addressed in order to identify profiles. This information was useful for benchmarking for the purposes of comparing the profiles or clusters according to their social network activity; especially for comparisons with the most active leading NPs. One fundamental aspect is that the content of social networks would contribute to more sustainable visitors behaviour, transmitting this philosophy [70].

In short, marketing can contribute to the sustainability of tourism by analysing the actions and applications arising from it on the basis of a marketing audit, attempting to reconcile the interests of the different agents involved in the management of parks under the basic principle of the conservation of those natural spaces.

From a theoretical point of view of marketing, the present study allows us to develop a new approach in the current paradigm of sustainable marketing based on marketing 4.0 [86]. In addition, for the CSR reports of NPs and for the study of their visitors [57], new approaches are needed with 
respect to the performance and behaviour of managers. The UN's sustainable development goals [37] highlight the need to link marketing, ecosystems and consumption to ensure sustainability.

\section{Limitations and Future Research}

Like all studies, this one also presents limitations. In the first place, the size of the sample for the completion of the marketing audit was very small. Nevertheless, large samples are not essential for this type of study, which consists of positioning items, so as to arrive at an acceptable diagnosis. The number of NPs selected for the social network analysis was also quite small. The largest areas were selected that constitute an acceptable representation of each country. Additionally, only the analysis of social networks and certain indicators were considered. These two social networks are the most widely used. The conclusions have therefore been conditioned by the above limitations.

As future lines of research, it would be interesting to increase the number of countries under analysis, as well as performing a comparison according to other channels of online communication used by NPAs such as, for example, their websites.

Social networks are gaining importance both with respect to knowing opinions and perceptions, and with regard to communication. For these reasons, in future research, the number of networks investigated and the items that are collected should be deepened, both those that collect quantitative information (visits, click, retweets, followers, etc.) and those that collect qualitative information, such as comments and opinions.

Author Contributions: These authors contributed equally to this work.

Funding: This research received no external funding.

Conflicts of Interest: The authors declare no conflict of interest. 


\section{Appendix A}

Table A1. Scores for importance and performance. Differences between importance and performance and significance level of Wilkinson test for the differences between importance and performance.

\begin{tabular}{|c|c|c|c|c|c|c|}
\hline \multirow[b]{2}{*}{ List of Items } & \multicolumn{2}{|c|}{$\begin{array}{l}\text { Importance } \\
\text { I }\end{array}$} & \multicolumn{2}{|c|}{$\begin{array}{l}\text { Performance } \\
\text { P }\end{array}$} & \multirow[b]{2}{*}{ I-P } & \multirow{2}{*}{$\begin{array}{l}\text { Sig. Level. } \\
\text { Wilcoxon Test for } \\
\text { Differences }\end{array}$} \\
\hline & Avg. & $\begin{array}{l}\text { Stan. } \\
\text { Dev. }\end{array}$ & Avg. & $\begin{array}{l}\text { Stand. } \\
\text { Dev. }\end{array}$ & & \\
\hline \multicolumn{7}{|l|}{ Marketing setting } \\
\hline Takes into account the principal economic events of the business setting before taking action. & 7.79 & 1.44 & 6.97 & 1.63 & 0.82 & 0.05 \\
\hline Seeks sustainable alternatives relating to environmental impact. & 9.23 & 0.81 & 8.36 & 1.01 & 0.87 & 0.15 \\
\hline Investigates on an annual basis the needs of its objective public. & 7.59 & 1.77 & 5.54 & 2.46 & 2.05 & 0.02 \\
\hline Has information available on objectives, strategies, strengths, and weaknesses of other parks. & 6.26 & 2.04 & 5.18 & 2.27 & 1.08 & 0.02 \\
\hline Knows and replies quickly to changes in the legislation that affects it. & 8.62 & 1.97 & 7.82 & 2.13 & 0.8 & 0.00 \\
\hline The park takes into account the principal technological changes in its area. & 6.85 & 1.97 & 5.9 & 1.96 & 0.95 & 0.07 \\
\hline \multicolumn{7}{|l|}{ Marketing strategy } \\
\hline $\begin{array}{l}\text { The mission statement is clearly worded, is feasible and known by all members of the } \\
\text { organization. }\end{array}$ & 8.85 & 1.97 & 8.1 & 1.60 & 0.75 & 0.22 \\
\hline It has a coherent and achievable marketing plan. & 6.69 & 2.24 & 3.46 & 2.64 & 3.23 & 0.00 \\
\hline Seeks new unsatisfied or niche market segments. & 6.23 & 3.03 & 4.54 & 2.97 & 1.69 & 0.01 \\
\hline Has a manual of corporate identity. & 7.92 & 2.29 & 6.44 & 3.15 & 1.48 & 0.05 \\
\hline The strategy of the park emphasizes a good relation with its interest groups. & 8.82 & 1.32 & 7.51 & 1.76 & 1.31 & 0.01 \\
\hline Internet forms part of the marketing strategy of the park. & 8.23 & 1.99 & 6.87 & 2.70 & 1.36 & 0.30 \\
\hline Know its competitive position, its threats and opportunities, to define objectives. & 7.74 & 2.28 & 6.15 & 2.65 & 1.59 & 0.08 \\
\hline \multicolumn{7}{|l|}{ Organization of Marketing } \\
\hline Employment positions defined with objectives, responsibilities, and authority to carry them out. & 8.88 & 1.54 & 6.8 & 2.51 & 2.08 & 0.03 \\
\hline Good relations and communication between the marketing department and others. & 6.54 & 3.39 & 4.95 & 3.47 & 1.59 & 0.00 \\
\hline Participants in marketing activities are properly trained. & 6.56 & 3.22 & 4.07 & 3.12 & 2.49 & 0.15 \\
\hline Employees are motivated by the achievement of marketing objectives. & 5.95 & 3.18 & 3.44 & 2.99 & 2.51 & 0.00 \\
\hline
\end{tabular}


Table A1. Cont.

\begin{tabular}{|c|c|c|c|c|c|c|}
\hline \multirow[b]{2}{*}{ List of Items } & \multicolumn{2}{|c|}{$\begin{array}{l}\text { Importance } \\
\text { I }\end{array}$} & \multicolumn{2}{|c|}{$\begin{array}{l}\text { Performance } \\
\text { P }\end{array}$} & \multirow[b]{2}{*}{ I-P } & \multirow{2}{*}{$\begin{array}{l}\text { Sig. Level. } \\
\text { Wilcoxon Test for } \\
\text { Differences }\end{array}$} \\
\hline & Avg. & $\begin{array}{l}\text { Stan. } \\
\text { Dev. }\end{array}$ & Avg. & $\begin{array}{l}\text { Stand. } \\
\text { Dev. }\end{array}$ & & \\
\hline \multicolumn{7}{|l|}{ Marketing Systems } \\
\hline $\begin{array}{l}\text { Monitors the achievement of marketing objectives (offline and online) and evaluates } \\
\text { shortcomings. }\end{array}$ & 5.61 & 3.29 & 2.93 & 2.84 & 2.68 & 0.00 \\
\hline The park uses web analytics tools. & 6.22 & 2.79 & 3.32 & 2.93 & 2.9 & 0.00 \\
\hline \multicolumn{7}{|l|}{ Marketing Productivity } \\
\hline Periodically studies the social impact that its services can provoke. & 7.37 & 2.25 & 4.39 & 2.63 & 2.98 & 0.01 \\
\hline Shares programs through collaborative agreements with other institutions. & 7.32 & 2.58 & 5.85 & 2.74 & 1.47 & 0.01 \\
\hline The cost of marketing activities is periodically reviewed and the appropriate measures are taken. & 5.34 & 3.32 & 2.73 & 3.07 & 2.61 & 0.00 \\
\hline \multicolumn{7}{|l|}{ Marketing Functions } \\
\hline Has a well-positioned web-page in the search engines rankings. & 7.88 & 2.37 & 5.93 & 2.70 & 1.95 & 0.00 \\
\hline Clearly defines its strategy on the quality of its services. & 7.73 & 2.56 & 5.68 & 3.05 & 2.05 & 0.01 \\
\hline The park has an internal communications system. & 8.02 & 2.30 & 6.8 & 2.98 & 1.22 & 0.17 \\
\hline The services present some added value that differentiates it from the other parks. & 7.46 & 2.35 & 6.49 & 2.45 & 0.97 & 0.01 \\
\hline Periodically reviews the efficiency of tourism and commercial operators with which it operates. & 6.46 & 3.12 & 3.73 & 3.27 & 2.73 & 0.02 \\
\hline Conducts direct marketing activities, online marketing, and database marketing. & 5.44 & 3.33 & 3.12 & 2.89 & 2.32 & 0.13 \\
\hline Communication is adapted to the concept of integrated communication for marketing. & 5.56 & 3.16 & 2.95 & 2.95 & 2.61 & 0.00 \\
\hline
\end{tabular}


Table A2. Facebook indicators. Differences by country.

\begin{tabular}{|c|c|c|c|c|c|}
\hline \multirow{2}{*}{ Item } & \multirow{2}{*}{ Country } & \multirow{2}{*}{ Cases } & \multicolumn{2}{|c|}{ Descriptive Statistics } & \multirow{2}{*}{$\begin{array}{l}\text { Significance Level } \\
\text { Kruskas-Wallis } \\
\text { Test }\end{array}$} \\
\hline & & & Mean & Stand. Dev. & \\
\hline \multirow{5}{*}{ FrontPage } & Mexico & 14 & 76.50 & 29.60 & \multirow{5}{*}{0.08} \\
\hline & Spain & 14 & 80.00 & 27.85 & \\
\hline & Italy & 15 & 83.60 & 23.40 & \\
\hline & USA & 14 & 98.79 & 4.54 & \\
\hline & Total & 57 & 84.70 & 24.44 & \\
\hline \multirow{5}{*}{ About } & Mexico & 15 & 52.00 & 27.32 & \multirow{5}{*}{0.01} \\
\hline & Spain & 15 & 58.33 & 28.22 & \\
\hline & Italy & 15 & 73.07 & 24.86 & \\
\hline & USA & 14 & 81.29 & 13.45 & \\
\hline & Total & 59 & 65.92 & 26.41 & \\
\hline \multirow{5}{*}{ Activity } & Mexico & 15 & 20.93 & 23.28 & \multirow{5}{*}{0.00} \\
\hline & Spain & 15 & 25.73 & 30.15 & \\
\hline & Italy & 15 & 46.33 & 31.62 & \\
\hline & USA & 14 & 76.57 & 19.15 & \\
\hline & Total & 59 & 41.81 & 33.92 & \\
\hline \multirow{5}{*}{ Response } & Mexico & 14 & 28.29 & 21.88 & \multirow{5}{*}{0.11} \\
\hline & Spain & 14 & 30.00 & 23.57 & \\
\hline & Italy & 15 & 17.60 & 22.31 & \\
\hline & USA & 14 & 37.71 & 15.98 & \\
\hline & Mexico & 57 & 28.21 & 21.85 & \\
\hline \multirow{5}{*}{ Photos } & Mexico & 14 & 53.07 & 45.81 & \multirow{5}{*}{0.00} \\
\hline & Spain & 14 & 30.43 & 33.38 & \\
\hline & Italy & 15 & 40.20 & 28.42 & \\
\hline & USA & 14 & 81.14 & 14.80 & \\
\hline & Total & 57 & 51.02 & 36.93 & \\
\hline \multirow{5}{*}{ Notes } & Mexico & 14 & 10.43 & 26.78 & \multirow{5}{*}{0.02} \\
\hline & Spain & 14 & 13.93 & 18.60 & \\
\hline & Italy & 15 & 30.73 & 24.84 & \\
\hline & USA & 14 & 8.79 & 8.79 & \\
\hline & Total & 57 & 16.23 & 22.33 & \\
\hline \multirow{5}{*}{ Videos } & Mexico & 14 & 7.07 & 12.91 & \multirow{5}{*}{0.24} \\
\hline & Spain & 14 & 5.64 & 9.53 & \\
\hline & Italy & 15 & 8.20 & 10.02 & \\
\hline & USA & 14 & 8.86 & 7.03 & \\
\hline & Total & 57 & 7.46 & 9.89 & \\
\hline \multirow{5}{*}{ Post_per_day } & Mexico & 14 & 0.09 & 0.13 & \multirow{5}{*}{0.00} \\
\hline & Spain & 13 & 1.12 & 3.57 & \\
\hline & Italy & 15 & 0.68 & 0.69 & \\
\hline & USA & 14 & 1.17 & 0.57 & \\
\hline & Total & 56 & 0.76 & 1.78 & \\
\hline \multirow{5}{*}{ Average_post_length } & Mexico & 14 & 149.57 & 239.24 & \multirow{5}{*}{0.00} \\
\hline & Spain & 14 & 240.86 & 400.80 & \\
\hline & Italy & 15 & 354.13 & 512.40 & \\
\hline & USA & 14 & 512.36 & 230.68 & \\
\hline & Total & 57 & 314.93 & 383.32 & \\
\hline
\end{tabular}


Table A2. Cont.

\begin{tabular}{|c|c|c|c|c|c|}
\hline \multirow{2}{*}{ Item } & \multirow{2}{*}{ Country } & \multirow{2}{*}{ Cases } & \multicolumn{2}{|c|}{ Descriptive Statistics } & \multirow{2}{*}{$\begin{array}{l}\text { Significance Level } \\
\text { Kruskas-Wallis } \\
\text { Test }\end{array}$} \\
\hline & & & Mean & Stand. Dev. & \\
\hline \multirow{5}{*}{ Events } & Mexico & 14 & 0.36 & 0.63 & \multirow{5}{*}{0.00} \\
\hline & Spain & 14 & 1.21 & 3.56 & \\
\hline & Italy & 15 & 4.00 & 8.58 & \\
\hline & USA & 14 & 6.43 & 9.04 & \\
\hline & Total & 57 & 3.02 & 6.79 & \\
\hline \multirow{5}{*}{ Pages_liked } & Mexico & 14 & 10.21 & 26.84 & \multirow{5}{*}{0.00} \\
\hline & Spain & 14 & 24.43 & 41.84 & \\
\hline & Italy & 15 & 31.60 & 39.06 & \\
\hline & USA & 14 & 56.07 & 40.39 & \\
\hline & Total & 57 & 30.60 & 40.12 & \\
\hline \multirow{5}{*}{ Native_FB_videos } & Mexico & 14 & 2.36 & 3.78 & \multirow{5}{*}{0.00} \\
\hline & Spain & 14 & 1.00 & 1.66 & \\
\hline & Italy & 15 & 5.40 & 6.69 & \\
\hline & USA & 14 & 15.79 & 8.32 & \\
\hline & Total & 57 & 6.12 & 8.05 & \\
\hline \multirow{5}{*}{ PTA } & Mexico & 14 & 64.50 & 94.64 & \multirow{5}{*}{0.00} \\
\hline & Spain & 14 & 452.43 & 1061.59 & \\
\hline & Italy & 15 & 880.07 & 1217.80 & \\
\hline & USA & 14 & $11,521.64$ & 9006.88 & \\
\hline & Total & 57 & 3188.44 & 6524.25 & \\
\hline \multirow{5}{*}{ Total_pages_like } & Mexico & 14 & 4380.86 & 7752.56 & \multirow{5}{*}{0.00} \\
\hline & Spain & 14 & $13,350.64$ & $21,939.16$ & \\
\hline & Italy & 15 & $31,443.40$ & $38,384.76$ & \\
\hline & USA & 14 & $422,666.79$ & $334,596.34$ & \\
\hline & Total & 57 & $116,442.58$ & $240,121.87$ & \\
\hline \multirow{5}{*}{ Engagement_rate } & Mexico & 15 & 4.53 & 9.07 & \multirow{5}{*}{0.05} \\
\hline & Spain & 15 & 1.60 & 2.41 & \\
\hline & Italy & 15 & 2.60 & 4.53 & \\
\hline & USA & 14 & 3.21 & 2.19 & \\
\hline & Total & 59 & 2.98 & 5.34 & \\
\hline
\end{tabular}

\section{References}

1. Gilmore, A.; Simmons, G. Integrating sustainable tourism and marketing management: Can National Parks provide the framework for strategic change? Strateg. Chang. 2007, 16, 191-200.

2. Saarinen, J. Tourism in the northern wildernesses: Wilderness discourses and the development of nature-based tourism in northern Finland. In Nature-Based Tourism in Peripheral Areas: Development or Disaster? Channel View Publications: Clevedon, UK, 2005; pp. 36-49.

3. Kruger, M.; Viljoen, A.; Saayman, M. Who visits the Kruger National Park, and why? identifying target markets. J. Travel. Tour. Mark. 2017, 34, 312-340.

4. Cooper, C. Tourism: Principles and Practice; Pearson Education: Upper Saddle River, NJ, USA, 2008.

5. Taher, S.H.M.; Jamal, S.A.; Sumarjan, N.; Aminudin, N. Examining the structural relations among hikers' assessment of pull-factors, satisfaction and revisit intentions: The case of mountain tourism in Malaysia. J. Outdoor Recreat. Tour. 2015, 12, 82-88.

6. Pomfret, G. Mountaineering adventure tourists: A conceptual framework for research. Tour. Manag. 2006, 27, 113-123.

7. Buckley, R. Adventure tourism products: Price, duration, size, skill, remoteness. Tour. Manag. 2007, 28, 1428-1433. 
8. Fredman, P. Determinants of visitor expenditures in mountain tourism. Tour. Econ. 2008, 14, $297-311$.

9. Heberlein, T.A.; Fredman, P.; Vuorio, T. Current tourism patterns in the Swedish mountain region. Mt. Res. Dev. 2002, 22, 142-149.

10. Saayman, M.; Saayman, A. Why travel motivation and socio-demographics matter in managing a national park. Koedoe 2009, 51, 1-9.

11. Cohen, E. The changing faces of contemporary tourism. Society 2008, 45, 330-333.

12. Viken, A.R.V.I.D. Ecotourism in Norway: Non-existence or Co-existence. In Ecotourism in Scandinavia: Lessons in Theory and Practice; CABI Pub.: New York, NY, USA, 2006; pp. 38-52.

13. Hall, C.M.; Boyd, S. Nature-based tourism in peripheral areas: Introduction. In Nature-Based Tourism in Peripheral Areas: Development or Disaster? Channel View Publications: Clevedon, UK, 2005; pp. 3-17.

14. Buckley, R. Parks and tourism. PLoS Biol. 2009, 7, e1000143. [CrossRef]

15. Lai, P.H.; Sorice, M.G.; Nepal, S.K.; Cheng, C.K. Integrating social marketing into sustainable resource management at Padre Island National Seashore: An attitude-based segmentation approach. Environ. Manag. 2009, 43, 985.

16. Xu, X.; Gursoy, D. A conceptual framework of sustainable hospitality supply chain management. J. Hosp. Mark. Manag. 2015, 24, 229-259.

17. Jamrozy, U. Marketing of tourism: A paradigm shift toward sustainability. Int. J. Cult. Tour. Hosp. Res. 2007, 1, 117-130.

18. Veisten, K.; Haukeland, J.V.; Baardsen, S.; Degnes-Ødemark, H.; Grue, B. Tourist segments for new facilities in national park areas: Profiling tourists in Norway based on psychographics and demographics. J. Hosp. Mark. Manag. 2015, 24, 486-510.

19. Becken, S.; Job, H. Protected areas in an era of global-local change. J. Sustain. Tour. 2014, 22, 507-527.

20. Tsiakali, K. User-generated-content versus marketing-generated-content: Personality and content influence on traveler's behavior. J. Hosp. Mark. Manag. 2018, 27, 946-972.

21. Goeldner, C.R.; Ritchie, J.B. Tourism Principles, Practices, Philosophies; John Wiley \& Sons: Hoboken, NJ, USA, 2007.

22. Hunt, S.D. General theories and the fundamental explananda of marketing. J. Mark. 1983, 47, 9-17.

23. Layton, R.A.; Grossbart, S. Macromarketing: Past, present, and possible future. J. Macromark. 2006, 26, 193-213.

24. Sharpley, R.; Pearce, T. Tourism, marketing and sustainable development in the English national parks: The role of national park authorities. J. Sustain. Tour. 2007, 15, 557-573.

25. Kim, M.; Knutson, B.J.; Han, J. Understanding employee delight and voice from the internal marketing perspective. J. Hosp. Mark. Manag. 2015, 24, 260-286.

26. Matzler, K.; Füller, J.; Renzl, B.; Herting, S.; Späth, S. Customer satisfaction with Alpine ski areas: The moderating effects of personal, situational, and product factors. J. Travel Res. 2008, 46, 403-413.

27. National Park Service. The National Parks Index 1916-2016; National Park Service: Washington, DC, USA, 2015.

28. Benson, C.; Watson, P.; Taylor, G.; Cook, P.; Hollenhorst, S. Who visits a national park and what do they get out of it? A joint visitor cluster analysis and travel cost model for Yellowstone National Park. Environ. Manag. 2013, 52, 917-928.

29. IUCN. From Nature, International Union for Conservation of Nature; IUCN: Gland, Switzerland, 2017. Available online: https://www.iucn.org/es/node/24506 (accessed on 30 September 2018).

30. UNEP-WCMC; IUCN. Protected Planet Report 2016; UNEP-WCMC: Cambridge UK; IUCN: Gland, Switzerland, 2016.

31. Zanon, D.; Hall, J.; Lockstone-Binney, L.; Weber, D. Development of a whole agency approach to market segmentation in parks. J. Leis. Res. 2014, 46, 563-592.

32. Leverington, F.; Costa, K.L.; Pavese, H.; Lisle, A.; Hockings, M. A global analysis of protected area management effectiveness. Environ. Manag. 2010, 46, 685-698.

33. Moyle, B.D.; Weiler, B.; Moore, S.A. Benefits that matter to managers: An exploratory study of three national park management agencies. Manag. Leis. 2014, 19, 400-419.

34. IUCN. Protected Planet; IUCN: Gland, Switzerland, 2017. Available online: https://protectedplanet.net/c/ protected-planet-report-2016/december-2016--global-update (accessed on 24 July 2019). 
35. Bramwell, B.; Richards, G.; Henry, I.; Jackson, G.; van der Straaten, J.; van't Zelfde, J.; Eizaguirre-Zarza, A.; Goytia-Prat, A.; Evans, D.M.; Laws, D.; et al. Sustainable Tourism Management: Principles and Practice; Tilburg University Press: Tilburg, The Netherlands, 1996.

36. Dewhurst, H.; Thomas, R. Encouraging sustainable business practices in a non-regulatory environment: A case study of small tourism firms in a UK national park. J. Sustain. Tour. 2003, 11, 383-403.

37. United Nations. Transforming Our World: The 2030 Agenda for Sustainable Development. 2012. Available online: https://sustainabledevelopment.un.org/content/documents/21252030\%20Agenda\%20for\% 20Sustainable\%20Development\%20web.pdf (accessed on 24 July 2019).

38. Belz, F.M.; Peattie, K.J. Sustainability Marketing: A Global Perspective; Wiley: Hoboken, NJ, USA, 2012.

39. Hanna, P.; Font, X.; Scarles, C.; Weeden, C.; Harrison, C. Tourist destination marketing: From sustainability myopia to memorable experiences. J. Destin. Mark. Manag. 2018, 9, 36-43.

40. Archer, D.; Wearing, S. Interpretation and marketing as management tools in national parks: Insights from Australia. J. Retail Leis. Prop. 2002, 2, 29-39.

41. Bitsani, E.; Kavoura, A. Host Perceptions of Rural Tour Marketing to Sustainable Tourism in Central Eastern Europe. The Case Study of Istria, Croatia. Proc. Soc. Behav. Sci. 2014, 148, 362-369.

42. Kemp, E.; Childers, C.Y.; Williams, K.H. A tale of a musical city: Fostering self-brand connection among residents of Austin, Texas. Place Brand. Public Dipl. 2012, 8, 147-157.

43. Sartori, A.; Mottironi, C.; Corigliano, M.A. Tourist destination brand equity and internal stakeholders: An empirical research. J. Vacat. Mark. 2012, 18, 327-340.

44. Kyle, G.; Graefe, A.; Manning, R.; Bacon, J. Predictors of behavioral loyalty among hikers along the Appalachian Trail. Leis. Sci. 2004, 26, 99-118.

45. AMA. American Marketing Association: Chicago, IL, USA; pp. 17-18. Available online: www. marketingpower.com (accessed on 15 December 2017).

46. Keefe, L.M. What is the meaning of 'marketing'. Mark. News 2004, 38, 17-18.

47. Kotler, P.; Kartajaya, H.; Setiawan, I. Marketing 3.0: Cómo atraer a los clientes con un marketing basado en valores; ED, LID: Madrid, Spain, 2010.

48. Wilson, L.A. Visitor attractions in Northern Ireland: The relationship between visitor number performance and ownership type 1990-2002. Curr. Issues Tour. 2004, 7, 146-180.

49. Donohoe, H.M. Sustainable heritage tourism marketing and Canada's Rideau Canal world heritage site. J. Sustain. Tour. 2012, 20, 121-142.

50. Hunt, S.D.; Vitell, S.J. The general theory of marketing ethics: A revision and three questions. J. Macromark. 2006, 26, 143-153.

51. Corbera, E.; Kosoy, N.; Tuna, M.M. Equity implications of marketing ecosystem services in protected areas and rural communities: Case studies from Meso-America. Glob. Environ. Chang. 2007, 17, 365-380.

52. Kihima, B.O. Unlocking the Kenyan Tourism Potential Through Park Branding Exercise. Tour. Rec. Res. 2014, 39, 51-64.

53. Reinius, S.W.; Fredman, P. Protected areas as attractions. Ann. Tour. Res. 2007, 34, 839-854.

54. Taplin, R.H. Competitive importance-performance analysis of an Australian wildlife park. Tour. Manag. 2012, 33, 29-37.

55. Kumar, V.; Rahman, Z.; Kazmi, A.A.; Goyal, P. Evolution of sustainability as marketing strategy: Beginning of new era. Proc. Soc. Behav. Sci. 2012, 37, 482-489.

56. Baker, M.J.; Saren, M. (Eds.) Marketing Theory: A Student Text; Sage: Thousand Oaks, CA, USA, 2016.

57. Font, X.; McCabe, S. Sustainability and marketing in tourism: Its contexts, paradoxes, approaches, challenges and potential. J. Sustain. Tour. 2017, 25, 869-883.

58. Lee, N.R.; Kotler, P. Social Marketing: Changing Behaviors for Good; Sage Publications: Thousand Oaks, CA, USA, 2015.

59. Joseph Pine, B., II; Gilmore, J.H. A leader's guide to innovation in the experience economy. Strategy Leadersh. 2014, 42, 24-29.

60. Agapito, D.; Valle, P.; Mendes, J. The sensory dimension of tourist experiences: Capturing meaningful sensory-informed themes in Southwest Portugal. Tour. Manag. 2014, 42, 224-237.

61. Kaczynski, A.; Crompton, J. An operational tool for determining the optimum repositioning strategy for leisure service departments. Manag. Leis. 2004, 9, 127-144. 
62. Lee, J.; Graefe, A.R.; Burns, R.C. Examining the antecedents of destination loyalty in a forest setting. Leis. Sci. 2007, 29, 463-481.

63. Quan, H. Please don't visit: Crowds and overdevelopment are hurting our National Parks. But what if Parks Canada were to try a little demarketing to encourage potential visitors to stay away? Mark. Mag. 2000, $105,14$.

64. Clarke, J. A synthesis of activity towards the implementation of sustainable tourism: Ecotourism in a different context. Int. J. Sustain. Dev. 2002, 5, 232-250.

65. Andam, K.S.; Ferraro, P.J.; Pfaff, A.; Sanchez-Azofeifa, G.A.; Robalino, J.A. Measuring the effectiveness of protected area networks in reducing deforestation. Proc. Natl. Acad. Sci. USA 2008, 105, 16089-16094.

66. Gaveau, D.L.; Epting, J.; Lyne, O.; Linkie, M.; Kumara, I.; Kanninen, M.; Leader-Williams, N. Evaluating whether protected areas reduce tropical deforestation in Sumatra. J. Biogeogr. 2009, 36, 2165-2175.

67. McFarlane, B.L.; Boxall, P.C.; Watson, D.O. Past experience and behavioral choice among wilderness users. J. Leis. Res. 1998, 30, 195-213.

68. Taylor, P.A.; Grandjean, B.D. Visitor satisfaction and support for park fees: Examining the effects of frontcountry, backcountry, and information in Rocky mountain national park. Proc. George Wright Forum 2009, 26, 12-21.

69. Rybako, S.; Seltzer, T. Dialogic communication in 140 characters or less: How Fortune 500 companies engage stakeholders using Twitter. Public Relat. Rev. 2010, 36, 336-341.

70. Manetti, G.; Bellucci, M. The use of social media for engaging stakeholders in sustainability reporting. Account. Audit. Account. J. 2016, 29, 985-1011.

71. Benckendorff, P.J.; Pearce, P.L. Australian tourist attractions: The links between organizational characteristics and planning. J. Travel Res. 2003, 42, 24-35.

72. Pearce, P.; Benckendorff, P. Benchmarking, usable knowledge and tourist attractions. J. Qual. Assur. Hosp. Tour. 2006, 7, 29-52.

73. Martilla, J.A.; James, J.C. Importance-performance analysis. J. Mark. 1977, 41, 77-79.

74. Levenburg, N.M.; Magal, S.R. Applying importance performance analysis to evaluate e-business strategies among small firms. E-Serv. J. 2005, 3, 29-48.

75. Bacon, D.R. A Comparison of Approaches to Importance-Performance Analysis. Int. J. Mark. Res. 2003, 45, $55-71$.

76. Azzopardi, E.; Nash, R. A critical evaluation of importance-performance analysis. Tour. Manag. 2013, 35, 222-233.

77. Lai, I.K.W.; Hitchcock, M. Importance-performance analysis in tourism: A framework for researchers. Tour. Manag. 2015, 48, 242-267.

78. Server, I. Importance-performance analysis: A valid management tool? Tour. Manag. 2015, 48, 43-53.

79. Dimanche, F.; Andrades, L. Methodological issues in cross-cultural tourism and hospitality research. In Handbook of Research Methods for Tourism and Hospitality Management; Edward Elgar Publishing: Cheltenham, UK, 2018.

80. Luque Martínez, T.; Doña Toledo, L.; Faraoni, N. Auditing Marketing and the Use of Social Media at Ski Resorts. Sustainability 2019, 11, 2868.

81. Kotler, P.; Dubois, B. Marketing Management; Publi-Union Editions: Paris, France, 1986.

82. Alpert, M. Identification of determinant attributes: A comparison of methods. J. Mark. Res. 1971, 8, $184-191$.

83. Abalo, J.; Varela, J.; Manzano, V. Importance values for importance performance analysis: A formula for spreading out values derived from preference rankings. J. Bus. Res. 2007, 60, 115-121.

84. Youden, W.J. Index for rating diagnostic tests. Cancer 1950, 3, 32-35. [PubMed]

85. Eizenberg, E.; Jabareen, Y. Social sustainability: A new conceptual framework. Sustainability 2017, 9, 68.

86. Kotler, P.; Kartajaya, H.; Setiawan, I. Marketing 4.0: Moving from Traditional to Digital; John Wiley \& Sons: Hoboken, NJ, USA, 2016.

(C) 2019 by the authors. Licensee MDPI, Basel, Switzerland. This article is an open access article distributed under the terms and conditions of the Creative Commons Attribution (CC BY) license (http://creativecommons.org/licenses/by/4.0/). 